\title{
José Siles Artés, traductor de los poetas lakistas
}

\author{
JUAN DE DIOS TORRALBO CABALLERO \\ Universidad de Granada
}

Fecha de recepción: 9 de febrero de 2009

Fecha de aceptación: 15 de abril de 2009

Resumen: Este artículo se centra en las traducciones de los poetas "lakistas" realizadas por José Siles Artés. En primer lugar, se desglosa una breve semblanza del traductor y luego se analiza su traducción del conocido poema de Wordsworth "Ode. Intimations of Immortality from Recollections of Early Childhood". Finalmente se alude al resto del legado creativo del autor.

Palabras clave: Poetas lakistas, Traducción al español, Recepción, José Siles Artés, Wordsworth, Coleridge, Southey.

Abstract: This paper focuses on the translation from the Lake Poets done by José Siles Artés. First of all, it is broken down a brief biographical sketch of the translator and, then, it is analyzed one of the famous poem by Wordsworth, "Ode. Intimations of Immortality from Recollections of Early Childhood". Finally, it is referred the rest of his creative legacy.

Key words: Lakist poets, Translation, Reception, José Siles Artés, Wordsworth, Coleridge, Southey.

INTRODUCCIÓN. BREVE SEMBLANZA DEL AUTOR EN SU LABOR DE PROFESOR, ESCRITOR, TRADUCTOR

José Siles Artés nace en Garrucha (1930), provincia de Almería, donde su padre ejerce de Maestro Nacional. La familia se traslada en la posguerra a Almería capital y allí cursa los estudios de Bachillerato. Tras unos meses de estudiante de Ciencias Químicas en Granada le llega la fecha de reemplazo (1950) y es destinado a Madrid, donde hace el servicio militar en el Ministerio de Marina. Reintegrado a la vida civil, ejercerá varios oficios; principalmente el de camarero en un colegio de Inglaterra, país donde una década más tarde ocupará la plaza de lector de español en la Universidad de Nottingham, tras trabajar de guía turístico en España e intérprete simultáneo en Estados Unidos, país por el que viajó extensamente.

Licenciado en Filología Inglesa y doctor por la Universidad Complutense de Madrid, es catedrático de inglés de Instituto y también de Escuela Universitaria, función esta que ha desempeñado en varias capitales del país, la última en Madrid. 
Ha participado en diversas actividades del Ateneo de Madrid, del que es antiguo socio, habiendo ocupado el cargo de Vicepresidente Segundo entre 1984 y 1988. Paralelamente a su labor didáctica, ha practicado siempre su vocación literaria, de la que son fruto publicaciones en los campos de la narrativa, la poesía y la traducción de poesía inglesa y norteamericana. Es, por otra parte, autor o coautor de libros didácticos, la mayoría destinados a la enseñanza del español para extranjeros, especialidad en la que se inició en la Universidad Internacional Menéndez Pelayo.

\section{LIBROS DE TRADUCCIÓN DE POESÍA}

En 1979 la luz de la imprenta alumbra Poesía inglesa.. Antología bilingüe, un trabajo que abarca desde el siglo XIV al XX. Contiene una introducción a cada poeta más notas y bibliografía. Las 169 páginas de que consta el libro son de suma utilidad para el docente. En 2006 publica su Poesía angloamericana. Antología bilingüe, revisión y considerable ampliación de la antología anterior.

A modo de publicación individual edita El Prólogo de los cuentos de Canterbury, de Geoffrey Chaucer (en 1983) así como La balada del marinero de antaño, de Samuel Taylor Coleridge, en 1981. Esta última obra explica la aventura de un marino durante un viaje en el mar y al comienzo centellea la bienaventuranza pero no tarda en surgir una nebulosa con la cual comienzan los desastres debido a las tormentas que padecen. Más adelante, el marino es rescatado por un eremita, y como penitencia ha de relatar su historia, la cual comienza de este modo:

It is an ancient Mariner,

And he stoppeth one of three.

'By thy long grey beard and glittering eye,

Now wherefore stopp'st thou me?

The Bridegroom's doors are opened wide,

And I am next of kin;

The guests are met, the feast is set:

May'st hear the merry din.'

He holds him with his skinny hand,

'There was a ship,' quoth he.

'Hold off! unhand me, grey-beard loon!'

Eftsoons his hand dropt he.

He holds him with his glittering eye--

The Wedding-Guest stood still,

And listens like a three years' child:

The Mariner hath his will. 
Marinero de antaño es

El que a uno detiene de tres.

"Por tu luenga barga gris y tus ojos de fuego,

¿por qué me detienes, di?

Las puertas del novio están de par en par

$Y$ yo soy deudo cercano.

Los huéspedes han llegado, el festejo listo está;

Escucha el alegre alboroto".

El marinero lo sujeta con su flaca mano.

"Érase un barco..." dice.

"Aparta! ¡Suelta, fantoche de barba gris!"

La mano le libra presto.

Lo retiene con sus ojos de fuego;

Inmóvil se queda el convidado,

Que escucha como un niño de tres años.

Ha ganado el marinero.

Según puede comprobarse, José Siles Artés mantiene una clara sujeción al texto original no sólo a través del molde estrófico, sino también a nivel del contenido, ya que pergeña una traducción semántica que sigue el texto original con una fidelidad destacable. El traductor mantiene intacta la anatomía del poema en los planos morfológico, sintáctico y semántico, aplicando para ello sendas modulaciones de forma que ofrece una fiel versión al lector español

\section{ANÁLISIS TRADUCTOLÓGICO DEL POEMA DE WORDSWORTH}

Este epígrafe se dedica a analizar traductológicamente el poema de Wordsworth titulado "Ode. Intimations of Immortality from Recollections of Early Childhood" y traducido como "Oda. Signos de inmortalidad en los recuerdos de la temprana infancia". El poema arranca con estos versos que, poco antes, ha compuesto el poeta inglés para "My Heart Leaps Up", los cuales son traducidos por Siles de la manera siguiente:

The child is father of the man;

And I could wish my days to be

Bound each to each by natural piety.

El niño es el padre del hombre, y ojalá en mí perdurara su bondad natural. 
Una de las directrices fundamentales del Romanticismo es la relación con la naturaleza de la que resulta la primacía del sentimiento, la búsqueda de lo sublime, de la individualidad. Algunos poetas románticos miran hacia un pasado inasible, arropado de lo primitivo y se muestran fascinados por la infancia o la inocencia.

La poesía romántica sublima, en ocasiones, incidentes y situaciones de la vida cotidiana, emplea un lenguaje entendible y lo adorna mediante un léxico pintoresco y cotidiano. Se está estrenando una lírica intimista y personal, como así expresarán Wordsworth y Coleridge en el prefacio a Lyrical Ballads (1798), verdadero manifiesto del Romanticismo británico:

To this knowledge which all men carry about with them, and to these sympathies in which without any other discipline than that of our daily life we are fitted to take delight, the poet principally directs his attention. (149)

Esta transparencia semántica de la poesía, reflejada de modo que pueda ser entendida por los lectores, aparece ornamentada por la dicción poética, se inspira en la naturaleza y sus temas se nutren de un descubrimiento arrobado de lo primitivo, de lo circundante, ello reflejado de modo que pueda ser entendido por los lectores. De hecho, indican que "poetry is the spontaneous overflow of powerful feelings: it takes its origin from emotion recollected in tranquillity" (151). La lírica se aleja de la preceptiva clásica y se impregna de afectividad a través de un lenguaje más sencillo para descubrir la naturaleza y, especialmente, los lagos.

Wordsworth compone su trabajo en Grasmere, entre 1802 y 1804. El poema es publicado en 1807 (Poems in Two Volumes) y recrea una oda a la inmortalidad. Se relaciona con otras composiciones que se inspiran en el paisaje rural de los lagos ingleses y presenta experiencias personales vividas en la naturaleza que alegran y agradan a quien vive en la metrópoli industrial. La evocación de recuerdos hace que el lector empírico se implique directa y activamente en la descodificación y comprensión de las tramas narradas.

La anatomía del poema se distribuye en once estrofas con un número de versos variable. En cuanto a la métrica destaca la anisometría así como el ritmo yámbico. El autor aplica sus recuerdos de infancia a su visión filosófica de la vida en edad madura. El autor explica en la introducción que se inspira en la filosofía platónica y considera que el alma habita un estado ideal previo a la ocupación del cuerpo, al cual retornará tras la muerte del cuerpo. El título, por tanto, confirma la inmortalidad del alma que brota y se relaciona con la temprana niñez, de ahí su famosa frase. "The Child is the Father of the Man". 
Encaminemos ahora los pasos hacia el análisis de los binomios textuales de modo detallado, aunque anotemos que las primeras cuatro estrofas intensifican el elemento natural así como la visión temprana, en tanto que la quinta la interpretamos como una fuente de inspiración para el poeta romántico, donde subyace un neoplatonismo arropado por el alma y la luz que describe. En la estrofa sexta la luz desaparece y en la siguiente el sujeto lírico se erige como un actor con roles definidos a modo de imitación. En la estrofa octava vemos un niño como el mejor filósofo y emparentado con la verdad sin desdeñar algunas preguntas sobre la pérdida de tal estado afortunado. Finalmente, las tres últimas estrofas del poema concilian la realidad a través de una mente filosófica. Se trata, en conjunto, de la inmortalidad como una explicación o pretexto para recrear el tema axial sobre la intensidad de la percepción.

1) El comienzo del poema objetiva a un sujeto lírico indicando cómo la naturaleza y todos los elementos materiales le parecieron divinos en una ocasión ya pretérita:

There was a time when meadow, grove, and stream,

The earth, and every common sight,

To me did seem

Apparelled in celestial light,

The glory and the freshness of a dream.

It is not now as it hath been of yore;--

Turn wheresoe'er I may,

By night or day.

The things which I have seen I now can see no more.

Hubo un tiempo en que prado, arroyo y arboleda,

la tierra y todo espectáculo cotidiano,

a mí me parecían

ornados de luz celestial,

el esplendor y la frescura de un sueño.

No es ya como era antaño,

a dondequiera que miro,

sea de día, sea de noche.

no veo ya lo que veía.

Como puede observarse, el traductor mantiene los elementos del fragmento y cambia sustancialmente la forma. Resalta, como procedimiento complementario, la inversión o el nuevo orden de los tres sustantivos en el primer verso ('meadow, grove and stream') ya que aparecen como una nueva serie creciente según el cómputo silábico: 'prado, arroyo y arboleda', lo cual añade una cualidad eufemística al ritmo del poema y no muta el 
contenido. En el verso segundo, el traductor embellece el nombre 'sight' al traducirlo como 'espectáculo' cuya etimología contiene el significado del elemento léxico original (spectaculum). El adjetivo que acompaña a dicho núcleo del sintagma nominal ('common') es traducido como cotidiano lo que puede entenderse como una introducción de información implícita en el texto original, o al menos una traducción muy adecuada según el manifiesto romántico del prefacio a las Baladas líricas ya que sus autores elogian el lenguaje cotidiano.

Asimismo, es destacable la traducción de 'the glory and the freshness of a dream' como 'el esplendor y la frescura de un sueño' que, completamente apegada al texto romántico original, prefiere el significado metafórico que porta 'esplendor' en lugar del calco más figurado y etéreo que contendría la traducción como 'gloria'.

El penúltimo verso de esta primera serie, 'By night or day' es traducido, mediante una inversión, como 'sea de día, sea de noche' con la que consigue, además, una transposición de grupo nominal a grupo preposicional la cual dota al verso de simetría y paralelismo no sólo sintáctico sino también semántico, morfológico y fonético.

Otro rasgo a destacar es la transposición en el verso final del grupo nominal 'the things' al pronombre 'lo', manteniendo así la función sintáctica pero variando la clase de unidad. La muestra original 'The things which I have seen I now can see no more' queda como 'no veo ya lo que veía', consiguiendo un efecto poético al evitar traducir "las cosas" y preferir utilizar el referido pronombre. El traductor mantiene la reiteración verbal por lo que conserva elementos morfosintácticos y su respectivo contenido significativo.

2) La segunda estrofa le recuerda que el arco iris aún le parece bello y justo si bien percibe que "there hath past [passed] away a glory from the earth."

The Rainbow comes and goes,

And lovely is the Rose,

The Moon doth with delight

Look round her when the heavens are bare,

Waters on a starry night

Are beautiful and fair;

The sunshine is a glorious birth;

But yet I know, where'er I go,

That there hath past away a glory from the earth.

Surge el arco iris y se deshace,

bella es la rosa,

y la luna con deleite

reina sobre el cielo raso;

las aguas en la noche estrellada 
son hermosas y claras,

$y$ el sol es un parto grandioso;

mas yo sé, dondequiera que esté,

que de la tierra un resplandor se fue.

La mutación más destacable, entre las estratagemas aplicadas por el traductor, es la modulación (de concreto a abstracto) que aparece en el primer verso cuando 'The Rainbow comes and goes' queda como 'Surge el arco iris y se deshace', lo cual añade la idea de emergencia y posterior fusión del elemento natural con el resto del cielo o del universo. En este caso este leve cambio resta la idea de movimiento que contienen los verbos originales pero añaden la armonía del surgimiento y fundición del arco iris.

El último verso que en la versión de Wordsworth es 'That there hath past away a Glory from the Earth' es trasladado así 'que de la tierra un esplendor se fue' resultando -al omitir 'there'- menos redundante que el original. Además, el traductor ha descargado levemente la latencia negativa que contiene el verbo 'pass away' traduciéndolo como 'se fue' y ha preferido anteponer complemento circunstancial de lugar desde el que parte 'el esplendor' lo que realiza gracias a la inversión del sintagma verbal respecto al sintagma preposicional. Estamos ante una modulación parcial de negativo a positivo si tenemos en cuenta únicamente esa porción oracional. Este cambio no merma el significado del poema y añade claridad al lector español ya que antepone la semántica locativa adverbial así como el sujeto del verbo.

El resto de la estrofa mantiene una fidelidad exquisita respecto al original y vierte el contenido apegándose al texto fuente como se aprecia en el comienzo, en cuyos versos sólo destaca la compensación o cambio de lugar de la conjunción coordinante 'and' que pasa de un verso a otro: 'And lovely is the Rose, / The Moon doth with delight / Look round her when the heavens are bare': 'bella es la rosa, / y la luna con deleite / reina sobre el cielo raso'. Puede observarse la filiación de la nueva versión española con el original y el mantenimiento de la cualidad poética a la vez que la conservación de la cualidad semántica a nivel tanto integral como particular.

3) La estrofa tercera afirma que la pena o el dolor que macera el interior de la persona no puede mermar la cualidad y la capacidad gozosa que ofrece la naturaleza.

Now, while the birds thus sing a joyous song,

And while the young lambs bound

As to the tabor's sound,

To me alone there came a thought of grief:

A timely utterance gave that thought relief, 
And I again am strong:

The cataracts blow their trumpets from the steep;

No more shall grief of mine the season wrong;

I hear the Echoes through the mountains throng,

The Winds come to me from the fields of sleep,

And all the earth is gay;

Land and sea

Give themselves up to jollity,

And with the heart of May

Doth every Beast keep holiday;--

Thou Child of Joy,

Shout round me, let me hear thy shouts, thou happy Shepherd-boy.

\author{
Ahora, mientras los pájaros cantan \\ gozosa canción y los corderitos \\ saltan como al compás del tambor, \\ sólo yo sentí una aflicción; \\ mas un oportuno canto me dio consuelo \\ y ya soy fuerte de nuevo. \\ Tocan sus trompetas las cataratas, \\ mi pena ya no ofenderá la estación, \\ oigo tropel de ecos por las montañas, \\ me llegan auras de la región del sueño, \\ y toda la tierra está dichosa; \\ tierra y mar \\ de gozo rebosan \\ y con corazón de Mayo \\ todo animal en fiesta está. \\ Y tú, niño de la alegría, \\ grita que te oiga yo, igrita junto a mí, oh, feliz pastor!
}

Al contraponer y contrastar el binomio textual puede confirmarse claramente que el poeta-traductor mantiene fielmente los elementos sintácticos y semánticos. Destaca la posposición del objeto directo del comienzo del verso primero al segundo así como el atraso del segundo verbo referido a los corderos del segundo verso -texto origen- al tercero en el texto meta: 'Now, while the birds this sing a joyous song, / And while the young lambs bound / As to the tabor's sound': 'Ahora, mientras los pájaros cantan / gozosa canción y los corderitos / saltan como al compás del tambor,'. Sin embargo, estas mutaciones no son taras ni cambian lo más mínimo el sentido ni el efecto poético de los dos referentes oracionales. En el verso cuarto se reduce el sintagma nominal con función de objeto directo ('To me alone there came a thought of grief': 'sólo yo sentí una aflicción') resultando en un cambio de la definición por el concepto. El poeta español, a través de esta implicitación, mantiene el poema equilibrado ya que no 
aminora la carga semántica ni permuta el sintagma puesto que es un sintagma nominal tanto en el texto de partida como en el texto de llegada. El mismo procedimiento se halla en el verso siguiente cuando 'thought of relief' queda como 'consuelo'. Mediante estas dos implicitaciones el traductor es congruente con su decisión toda vez que mantiene el paralelismo morfológico y sintáctico de ambos grupos léxicos.

De esta estrofa sobresalen varios procedimientos de traducción de los que subrayamos la expansión del verso noveno al traducir 'Echoes' como 'tropel de ecos', la modulación de 'Winds' por 'auras' (de concreto a abstracto) lo cual añade un hálito poético a la composición, al igual que consigue al modular 'Give themselves up to jollity' por 'de gozo rebosan'. Al final del fragmento el poeta se dirige al sujeto lírico a través del vocativo 'Thou Child of Joy' que, lejos de perder matices del original, es realzado por la conjunción que el traductor antepone y mediante la forma de aposición que genera: 'y tú, niño de la alegría'. El recreador aplica sendos procedimientos traslaticios que generan un efecto poético y mantiene una fidelidad notoria respecto al original como puede leerse en el último verso de este ramo: 'Shout round me, let me hear thy shouts, thou happy Shepherd-boy!': 'grita que te oiga yo, igrita junto a mí, oh, feliz pastor!

4) En la estrofa cuarta la percepción del sujeto lírico aflora de modo muy positivo y gozoso, sin embargo este sentimiento o percepción pronto se desvanece.

\footnotetext{
Ye blessed creatures, I have heard the call

Ye to each other make; I see

The heavens laugh with you in your jubilee;

My heart is at your festival,

My head hath its coronal,

The fulness of your bliss, I feel--I feel it all.

Oh evil day! if I were sullen

While Earth herself is adorning,

This sweet May-morning,

And the Children are culling

On every side,

In a thousand valleys far and wide,

Fresh flowers; while the sun shines warm,

And the Babe leaps up on his Mother's arm:--

I hear, I hear, with joy I hear!

--But there's a Tree, of many, one,

A single field which I have looked upon,

Both of them speak of something that is gone;

The Pansy at my feet

Doth the same tale repeat:
} 
Whither is fled the visionary gleam?

Where is it now, the glory and the dream?

Felices criaturas, he oído las llamadas que unas a otras os hacéis; veo al cielo reír en vuestro jubileo; mi corazón está en vuestro festival, y plenamente vuestra dicha siento.

Aciago sería este día si yo triste estuviera mientas la tierra misma engalana esta dulce mañana de Mayo, y frescas flores los niños recogen por doquier en mil valles lejanos.

Mientas calientan los rayos del sol y en los brazos de su madre brinca el bebé, yo escucho, escucho, icon gozo escucho! Mas hay un árbol, uno entre muchos, y un cierto prado por mí contemplado, que hablan de algo que se fue.

La trinitaria a mis pies repite la misma canción:

¿Adónde huyó el visionario fulgor?

¿Qué fue del sueño y el esplendor?

En el verso introductorio observamos un cambio operado en el número ya que el objeto directo de la oración 'I have heard the call' cambia a plural en 'he oído las llamadas'. La transposición que realiza el traductor consigue que el agente de la frase concuerde con el antecedente que es 'blessed Creatures', el cual aparece en plural.

En el verso quinto ('My head hath its coronal') se localiza otra transposición en la función sintáctica de la unidad ('su guirnalda llevo sobre la cabeza') ya que el sujeto del texto original se convierte en complemento circunstancial de lugar en la recreación y el objeto directo del texto primero ('its coronal') pasa a sujeto del texto meta. Además, a nivel semántico se aprecia un embellecimiento del término al traducir 'coronal' como 'guirnalda'. En consonancia con las decisiones operadas en la traducción, el poeta español emplea el verbo 'llevar', muy acorde con en cambio sintáctico señalado, en lugar de traducirlo literalmente como 'tiene'.

La traducción del verso siguiente ('The Furness of your bliss, I feelIfeel it all') no mantiene la reiteración de sujeto y verbo que tiene el original ('Ifeel-I feel') ('y plenamente vuestra dicha siento'), sin embargo esta omisión del énfasis personal ya ha sido compensada a priori con el empleo del sujeto animado en el verso anterior. 
El contenido que va desde el verso noveno al duodécimo es digno de mención por lo que atañe a la maestría de Wordsworth y por lo que aplica José Siles en su versión. El texto traducido mantiene una estricta fidelidad en el verso noveno y duodécimo (This sweet May-morning, / And the Children are culling / On every slide, / In a thousand valleys far and wide, / Fresh flowers, (...)': esta dulce mañana de Mayo, / y frescas flores los niños recogen / por doquier / en mil valles lejanos'). Los versos décimo y undécimo presentan unos cambios mínimos que no destiñen el vigor del original, pues el décimo antepone el objeto directo que está en el décimotercero en el texto de partida. Siles, al realizar este hipérbaton, acerca el objeto al sujeto ('frescas flores los niños recogen') y tras esta serie oracional sitúa a los dos complementos circunstanciales; el inglés hace que los dos adverbiales de lugar aparezcan, también en hipérbaton, en mitad del verbo y el objeto. Ambos escritores aplican un desorden sintáctico según el orden lógico de los elementos oracionales, si bien Wordsworth prefiere darle al sujeto un lugar inicial y posponer los circunstanciales, mientras que Siles realiza el cambio de orden entre el verbo y el sujeto. En el poema inglés hay que leer más para aprehender el objeto directo ya que se distancia dos versos de su verbo, en el español se leen seguidos. Por tanto, puede inferirse que ambos aplican esta figura estilística pero con diferentes fines.

Es reseñable el paralelismo que mantiene el traductor con el texto inglés, ya que 'I hear, I hear, with joy I hear' es vertido como 'yo escucho, escucho, jcon gozo escucho!' dejando inalterados los tres verbos en lo que corresponde a la semántica y al lugar que ocupan en el verso.

Un cambio semántico o modulación se lee en el verso 'Doth the same tale repeat' traducido como 'repite la misma canción'. El español omite el hipérbaton (versión inglesa: enfatizador, objeto directo y verbo; versión española: verbo y objeto directo), se desprende del 'doth' con aroma arcaico y con función enaltecedora del original y traduce 'same tale' por 'misma canción' por lo que altera ligeramente el sustantivo toda vez, al añadirle música, transforma el significado de narración por el sustantivo 'canción'.

El verso vigésimo segundo ('Where is it now, the Glory and the dream': '¿qué fue del sueño y el esplendor?') sigue, de modo congruente, la estela que ya observamos en la primera estrofa al traducir 'glory' por 'esplendor'. Anotemos aquí que en la estrofa sexta 'glories' aparece como 'la gloria', en cuyo caso ha tornado el número plural a singular y, quizá por este motivo, lo interpreta como 'la gloria'. La diferencia más notable que se aprecia ahora es que cambia de orden los atributos (Siles prefiere referirse 'al sueño' antes que al 'esplendor') y destaca, igualmente, un cambio tempo verbal del presente al pasado. El sentido, significado y referente, empero, permanecen incólumes. 
5) La estrofa quinta emana en disquisición filosófica: "Our birth is but a sleep and a forgetting" y las almas, explica, se originan en un estado puro y glorioso. Los niños pequeños conservan y mantienen una memoria del paraíso la cual glorifica su experiencia en la tierra; los jóvenes -sin embargo- comienzan a perderla.

Our birth is but a sleep and a forgetting:

The Soul that rises with us, our life's Star,

Hath had elsewhere its setting,

And cometh from afar:

Not in entire forgetfulness,

And not in utter nakedness,

But trailing clouds of glory do we come

From God, who is our home:

Heaven lies about us in our infancy!

Shades of the prison-house begin to close

Upon the growing Boy,

But he beholds the light, and whence it flows,

He sees it in his joy;

The Youth, who daily farther from the east

Must travel, still is Nature's Priest,

And by the vision splendid

Is on his way attended;

At length the Man perceives it die away,

And fade into the light of common day.

Nuestro nacimiento es solo un sueño y un olvido.

El alma que con nosotros se alza, nuestra alma,

ha tenido en otro lugar su ocaso

y procede de un ámbito lejano.

No en completo olvido

ni en total desnudez,

sino con una estela de esplendor, venimos

de Dios, que es nuestro hogar.

El cielo nos circunda en nuestra infancia;

sombras de prisión empiezan a caer

sobre el muchacho que crece,

pero aún ve la luz y de dónde procede:

su júbilo se la hace ver.

El joven, que del Oriente cada día se aleja,

es sacerdote de la Naturaleza todavía,

mientras la brillante aureola,

en su caminar le acompaña.

El hombre después la ve palidecer

hasta diluirse en la luz del día normal. 
El segundo verso de esta serie presenta un leve cambio en el orden sintáctico del complemento circunstancial de compañía ('with us') que está realizado para evitar el sonido redundante que ocasionaría la posible epizeuxis y reduplicación que ahora se señala. 'The Soul that rises with us, our life's Star' es traducido como 'El alma que con nosotros se alza, nuestra alma' omitiendo 'our life's Star'. El sintagma 'our life's Star' aparece como 'nuestra alma'. De una parte destaca la modulación de abstracto a concreto, ya que se aminora el lenguaje metafórico original y se traslada repitiendo el sustantivo alma que ya estaba a principio de verso; de otra destaca el hipérbaton referido que evita la cacofonía que provocaría esta otra traducción: 'El alma que se alza con nosotros, nuestra alma'.

El verso séptimo traduce, ahora por tercera vez, el significante 'glory' como 'esplendor'. Y por el prurito de señalar otro intento de Siles para embellecer el poema, añadamos que el sintagma completo 'clouds of glory' es escrito en español como 'estela de esplendor'.

Otro cambio en la traducción es la mutación operada en el verso décimotercero ya que la estructura (sujeto, verbo, objeto directo, complemento circunstancial de lugar) aparece cambiada no sólo a nivel sintáctico sino también en el enfoque semántico, ya que el circunstancial de lugar aparece como sujeto ('su júbilo').

La pretendida concreción que venimos objetivando en la traducción es acentuada de nuevo en los versos finales que nos ocupan cuando 'And by the vision splendid' es traducido como 'mientras la brillante aureola'. La conjunción sumatoria se torna en conjunción temporal. Una transformación similar se encuentra en el último verso, al cambiar 'and' por 'hasta', conjunción esta última que, seguida de infinitivo, indica el término de la acción principal. Señalemos, asimismo, la selección atinada del re-escritor al trasladar el premodificador 'common' de modo diferente en esta estrofa (que es traducido por 'normal' refiriéndose a 'día') y en la primera (que es traducido por 'cotidiano' refiriéndose a 'espectáculo' en el segundo verso).

6) La estrofa sexta establece que los adultos, completamente distraídos por los asuntos del terruño, olvidan por completo la inocencia del niño.

Earth fills her lap with pleasures of her own;

Yearnings she hath in her own natural kind,

And, even with something of a Mother's mind,

And no unworthy aim,

The homely Nurse doth all she can

To make her Foster-child, her Inmate Man,

Forget the glories he hath known,

And that imperial palace whence he came. 


\author{
La tierra llena su regazo de goces propios; \\ siente ternura por todas sus criaturas, \\ y hasta con instinto de madre \\ y loable intento, \\ la humilde nodriza se desvela \\ porque su hijo de leche, su pupilo ya hombre, \\ olvide la gloria que ha conocido \\ y el palacio imperial de donde partió.
}

Debido a la brevedad de este segmento, pensamos es un buen momento para gozar de la lectura de sus ocho versos en ambas versiones ya que se entrevé un efecto poético magistralmente conseguido, pues apenas se alteran los elementos y el texto meta comunica una aureola marcadamente literaria y poética al receptor. Por ejemplo, 'her lap' es traducido como 'su regazo', 'came' como 'partió'.

Se infiere que Siles Artés, cual antólogo, busca la palabra adecuada e intenta no cambiar en demasía la estructura siempre que el efecto y el resultado finales sean óptimos, como ocurre en este espécimen. Cuando el traductor muta algún elemento no cambia el significado original y añade, en ocasiones, más información que coadyuva a la inteligibilidad del poema. Sirvan de ejemplo el caso de 'all she can' traducido como 'se desvela', the glories' traducido ahora en singular y como 'la gloria' o la adición en verso sexto ('To make her Foster-child, her Innate man,': porque su hijo de leche, su pupilo ya hombre').

7) A continuación, el personaje del poema observa un niño de seis años imitando el comportamiento adulto "as if his whole vocation / Were endless imitation".

Behold the Child among his new-born blisses, A six years' Darling of a pigmy size!

See, where 'mid work of his own hand he lies, Fretted by sallies of his mother's kisses,

With light upon him from his father's eyes!

See, at his feet, some little plan or chart,

Some fragment from his dream of human life,

Shaped by himself with newly-learn\{ $e\} d$ art

A wedding or a festival,

A mourning or a funeral;

And this hath now his heart,

And unto this he frames his song:

Then will he fit his tongue

To dialogues of business, love, or strife:

But it will not be long

Ere this be thrown aside, 
And with new joy and pride

The little Actor cons another part;

Filling from time to time his "humorous stage"

With all the Persons, down to palsied Age,

That Life brings with her in her equipage;

As if his whole vocation

Were endless imitation.

Contemplad al tierno y bienaventurado niño,

¡una hermosura de seis años con talla de pigmeo!

Vedlo boca arriba agitando sus manos,

mientras la madre le colma de besos

y el padre le baña con la luz de sus ojos.

Ved, a sus pies, un pequeño plano o gráfico,

un fragmento de vida soñada,

trazado por él mismo con arte recién aprendido;

una boda o un festival,

un duelo o un funeral,

en esto pone el corazón

y para esto conforma su canción.

Luego adaptará su lengua

para hablar de negocios, lucha o amor,

pero al poco tiempo,

todo ello será desechado,

el pequeño actor asumirá otro papel,

escenificando de cuando en cuando

todos los personajes, incluida la perlática edad,

que en el cortejo de la vida van,

como si toda su vocación

fuese una incesante imitación.

En el comienzo de la esta parte se observa una modificación de los elementos tornándose el grupo preposicional ('among his new-born blisses') en adjetivo ('al tierno y bienaventurado niño'). Además de esta transposición, el traductor tiñe su texto con cualidades muy emotivas y las ubica más cerca del referente. De hecho, 'new-born' es trasladado como 'tierno' y 'blisses' que está en el sintagma preposicional referido a su antecedente 'Child' aparece premodificando al núcleo del sintagma nominal español ('bienaventurado niño'). El deseo esclarecedor del traductor sigue notándose a la vez que destella un sentido más conmovedor de cara al lector o receptor en el polisistema meta.

El quinto verso ('With Light upon him from his father's eyes!') ofrece una imagen de radiación luminosa desde el padre, pero es el lector quien tiene que imaginar el verbo, ya que es un verso y una oración exclamativa sin verbo; en la traducción ('y el padre le baña con la luz de sus ojos') se 
coteja un afán de concreción o de explicitación, puesto que Siles añade 'baña' en aras de la claridad y la transparencia del contenido. Estimamos que es para acercar, de este modo, el tejido poético al lector.

En el tramo final de la estrofa resaltan otras mutaciones en aras de la inteligibilidad y la claridad que venimos aduciendo pues si bien se esfuman los sintagmas 'humorous stage' o 'in her equipage' no aminoran la carga semántica que se lee en origen. Además si se revisa la terminación de la estrofa se entrevé un deseo clarificador por parte del traductor ya que el fragmento resulta más concreto o locativo en el plano espacial figurado que dibuja el poema: 'Filling from time to time his humorous stage'/With all the Persons, down to palsied Age,/That Life brings with her in her equipage;/Were endless imitation': 'escenificando de cuando en cuando,/todos los personajes, incluida la perlática edad,/que en el cortejo de la vida van,/como si toda su vocación/fuese una incesante imitación'.

8) La estrofa octava hace que el sujeto lírico se dirija al niño preguntándose la razón por la cual ("thou best Philosopher" y "Mighty Prophet") imita el comportamiento adulto.

Thou, whose exterior semblance doth belie

Thy Soul's immensity;

Thou best Philosopher, who yet dost keep

Thy heritage, thou Eye among the blind,

That, deaf and silent, read'st the eternal deep,

Haunted for ever by the eternal mind,--

Mighty Prophet! Seer blest!

On whom those truths do rest,

Which we are toiling all our lives to find,

In darkness lost, the darkness of the grave;

Thou, over whom thy Immortality

Broods like the Day, a Master o'er a Slave,

A Presence which is not to be put by;

Thou little Child, yet glorious in the might

Of heaven-born freedom on thy being's height,

Why with such earnest pains dost thou provoke

The years to bring the inevitable yoke,

Thus blindly with thy blessedness at strife?

Full soon thy Soul shall have her earthly freight,

And custom lie upon thee with a weight,

Heavy as frost, and deep almost as life!

Tú, cuyo aspecto disimula

la inmensidad de tu alma;

tú magno filósofo, que aún conservas

tu herencia; tú, vidente entre los ciegos, 


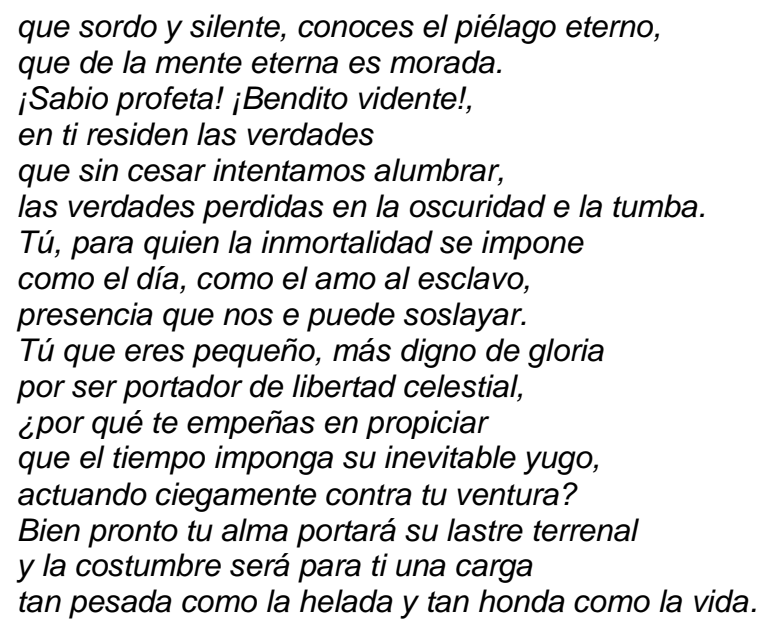

El estilo directo que emana del vocativo inicial es mantenido fielmente en el texto recreado y hasta el verso noveno todos los componentes verbales se quedan en el mismo lugar que tienen en el texto inglés destacándose el cambio de los elementos en el segundo verso debido a la traducción del genitivo ('Thy Soul's immensity': la inmensidad de tu alma) que, aun permaneciendo literal, ocasiona la pérdida de la anáfora del sonido repetido en los cuatro primeros versos del original. Mientras en el texto fuente se duplica el sonido fricativo (de 'thou' y 'thy', con una aparición alterna), en español se mantiene la reiteración de nuestra consonante oclusiva dental ('tú). El traductor, sagazmente, en los versos quinto y sexto genera otro sonido anafórico repetido dos veces, que compensa, en parte, la pérdida antedicha.

En el verso cuarto el traductor parece modular, a nivel morfológico, un singular ('the blind') por un plural ('los ciegos); sin embargo Siles Artés está especificando el sintagma nominal inglés -elíptico- 'the blind people'. La diferencia que se comprueba -en la semántica- es el efecto sinecdóquico que emerge al traducir 'thou Eye' por 'tú, vidente'; lo cual siembra un significado muy preciso para el lector de habla española.

Resalta, de nuevo, el embellecimiento a nivel de significado, por ejemplo en la versión 'piélago eterno' del quinto verso generada a partir de 'eternal deep'. El traductor ha cambiado un participio ('Haunted fore ver by the eternal mind', con función de oración adjetiva con el relativo omitido) por una secuencia oracional en la que el agente de la oración inglesa ('by the eternal mind') se convierte en complemento del nombre ('de la mente eterna es morada') y donde ha creado un verbo copulativo para correlacionar su 
nuevo atributo ('morada') el cual procede de una transposición al cambiar un grupo adjetival ('Haunted (...)') por un grupo nominal ('morada').

Otro cambio que acerca el significado de la trama al receptor español es el que se vislumbra en el verso noveno ('Which we are toiling all our lives to find,'), ya que el verbo principal junto al complemento circunstancial de tiempo ('are toiling all our lives') se condensa en la expresión ('sin cesar'). El infinitivo con función de objeto directo del verbo anterior ('to find') queda como el único verbo de la tirada meta. Ahora bien, las omisiones explicadas son compensadas por el cambio de matiz semántico en el verbo que no es traducido como 'encontrar' sino como 'intentamos alumbrar', lo cual recoge parte del significado disipado en las omisiones.

La traducción del verso décimo 'In Darkness lost, the Darkness of the grave;' como'las verdades perdidas en la oscuridad de la tumba', aunque no recrea la reiteración del nombre 'darkness', gana un símil y una explicitación 'como las verdades perdidas' ya que repite el antecedente que está dos versos atrás ('truths').

9) En la estrofa novena, el protagonista se regocija con los recuerdos de la infancia ("those shadowy recollections" that "are yet a master light of all our seeing") los cuales le inspiran y enaltecen.

O joy! that in our embers

Is something that doth live,

That Nature yet remembers

What was so fugitive!

The thought of our past years in me doth breed

Perpetual benediction: not indeed

For that which is most worthy to be blest;

Delight and liberty, the simple creed

Of Childhood, whether busy or at rest,

With new-fledged hope still fluttering in his breast:--

Not for these I raise

The song of thanks and praise

But for those obstinate questionings

Of sense and outward things,

Fallings from us, vanishings;

Blank misgivings of a Creature

Moving about in worlds not realised,

High instincts before which our mortal Nature

Did tremble like a guilty thing surprised:

But for those first affections,

Those shadowy recollections,

Which, be they what they may

Are yet the fountain-light of all our day,

Are yet a master-light of all our seeing; 
Uphold us, cherish, and have power to make

Our noisy years seem moments in the being

Of the eternal Silence: truths that wake,

To perish never;

Which neither listlessness, nor mad endeavour, Nor Man nor Boy,

Nor all that is at enmity with joy,

Can utterly abolish or destroy!

Hence in a season of calm weather

Though inland far we be,

Our Souls have sight of that immortal sea

Which brought us hither,

Can in a moment travel thither,

And see the Children sport upon the shore,

And hear the mighty waters rolling evermore.

Oh alegría, cuyos rescoldos

en nosotros pervive,

que nuestro ser recuerda,

aunque fuera tan fugaz.

El evocar los tiernos años me inspira

perpetua la bendición; no en verdad

por lo que más merece ser bendecido:

la alegría y la libertad, el simple credo

de la infancia, activa o en reposo,

cuando la esperanza aún late en su pecho.

Por ninguno de esas razones entono

ese canto de gratitud y alabanza,

sino por aquellas pertinaces preguntas

sobre sensaciones y el mundo exterior,

desprendimientos nuestros, emanaciones,

presentimientos inconcretos de una criatura

que se movía en mundos no realizados,

excelsos instintos ante los que la mortal naturaleza

temblaba como sorprendida y culpable.

Por aquellas primeras emociones,

aquellos brumosos recuerdos

que, aunque de naturaleza desconocida,

son una fuente de luz que nunca nos abandona

un faro que siempre nos guía,

nos sostiene, nos protege y hace que

nuestros ruidosos años parezcan instantes en el ser

del eterno silencio: verdades que despiertan

para nunca perecer,

que ni apatía ni loco intento,

ni hombre ni muchacho,

ni nada que se oponga a la alegría, 


\author{
pueden anular ni matar. \\ Desde ahí, en época de bonanza, \\ aunque muy tierra adentro estemos, \\ nuestras almas divisan el mar inmortal \\ que a esta orilla nos trajo, \\ ven a los niños jugar en la playa \\ y escuchan el eterno rodar del potente mar.
}

El comienzo de este grupo presenta una variación sutil que omite un posesivo ('our') para recuperarlo un verso después mediante otra forma pronominal ('en nosotros') a modo de circunstancial de lugar: 'O Joy! That in our embers/ls something that doth live,': 'Oh alegría, cuyos rescoldos/en nosotros pervive'. El significado no se altera. Tampoco trocan el sentido las mutaciones que se observan en los versos siguientes: 'That nature yet remembers/What was so fugitive': 'que nuestro ser recuerda, / aunque fuera tan fugaz'. 'Nature' aparece como 'ser' y el comienzo de la exclamación inglesa ('what') es presentada, en español, como adversativa.

El sujeto del verso quinto ('The thought of our past years') es modulado de esta manera: 'El evocar los tiernos años' lo cual agrega el proceso evocador a la vez que traslada el adjetivo 'past' como 'tiernos'. Conserva el sentido por completo y brilla la aspiración poética del traductor.

Del mismo modo que en la estrofa cuarta hemos hallado 'same tale' traducido como 'misma canción'; ahora la oración, en encabalgamiento, que aparece entre los versos undécimo y duodécimo ('Not for there I raise/the song of thanks and praise') es traducida como 'Por ninguna de esas razones entono/este canto de gratitud y alabanza'. Siles Artés ha querido esmaltar el significado del verbo, resultando 'entono' como equivalente a 'alzo' o 'levanto', que sería la versión más literal. El contenido permanece íntegro así como el encabalgamiento original.

La rememoración de los recuerdos felices emerge en la parte final de la estrofa y son recreados con un orden magistral (20-28) en el que destaca la unión con el original. El verso vigésimo segundo ('Which, be they what they may,') es recreado como 'que, aunque de naturaleza desconocida' tras el cual sigue éste: 'Are yet the fountain-light of all seeing', vertido como 'son una fuente de luz que nunca nos abandona' donde vuelve el poeta a la literalidad del original modulando únicamente 'of all our day' por la expresión equivalente 'nunca nos abandona' la cual mantiene el sentido inicial. Una nueva modulación (de forma a función) destaca en el trasvase del verso vigésimo cuarto ('Are yet a master-light of all seeing:': 'son una fuente de luz que nunca nos abandona'), sin alterar el significado.

En el tramo final de la estrofa, que también mantiene el apego al original, se contempla una adición en aras de la claridad, de la recta ubicación del 'cronotopo', concretamente en el verso antepenúltimo cuyo 
original dice 'Which brought us hither,' y el resultado es 'que a esta orilla nos trajo'. Se trata de una modulación de una metáfora a otra diferente cuya función es dilucidar el significado y aportar precisión al lector.

10) La penúltima estrofa se centra en el canto de los pájaros y en el esparcimiento de los corderos jóvenes. En lugar de llorar la pérdida de la inocencia y la sabiduría infantil, el sujeto desea "find / Strength in what remains behind" para desarrollar una "mente filosófica" brotada de la conciencia de la mortalidad.

Then sing, ye Birds, sing, sing a joyous song!

And let the young Lambs bound

As to the tabor's sound!

We in thought will join your throng,

Ye that pipe and ye that play,

Ye that through your hearts to-day

Feel the gladness of the May!

What though the radiance which was once so bright

Be now for ever taken from my sight,

Though nothing can bring back the hour

Of splendour in the grass, of glory in the flower;

We will grieve not, rather find

Strength in what remains behind;

In the primal sympathy

Which having been must ever be;

In the soothing thoughts that spring

Out of human suffering;

In the faith that looks through death,

In years that bring the philosophic mind.

Así pues, jcantad pajarillos, cantad!

¡Y dejad que los corderitos brinquen como al son del tambor.

Nosotros nos uniremos con la intención

a vosotros que trináis y que jugáis,

y que hoy con todo el corazón

sentís el gozo que mayo trae.

Y aunque a mi vista esté ya negada

la luz que antaño fue tan intensa,

aunque nada puede restituir su esplendor

a la hierba, y a la flor su grandeza,

no caeremos en la aflicción, sino que hallaremos

fortaleza en lo que atrás hemos dejado,

en la primigenia bondad

que, habiendo sido, debe siempre ser;

en el consuelo que brota 
del sufrimiento humano,

en la fe que mira más allá de la muerte, en los años que nos hacen sabios.

El primer verso traducido abrevia la densidad pero mantiene la reiteración léxica del verbo (epizeuxis) si bien para no reiterar el significado verbal el traductor prefiere omitir el objeto directo (que es en el texto origen una germinación): 'Then sing, ye Birds, sing, sing a joyuos song!': 'Así pues, ¡cantad pajarillos, cantad!'

El sintagma nominal del segundo verso ('young Lambs') es traspasado con el diminutivo ('corderitos') lo cual mantiene el contenido del adjetivo figurando, el significante de cordero pascual o recental, cuya designación implícita es el estado feliz y la inocencia que late en la infancia. El símil contiguo se mantiene intacto, cuya finalidad es marcar el compás del canto o de los brincos de estos animales.

Los versos quinto y sexto se despojan de la anáfora y el paralelismo que tienen al comienzo ('Ye that $(. .$.$) 'YYe that (\ldots)$ ': 'a vosotros que $(\ldots) / y$ que (...)'). El efecto de esta anáfora, no obstante, es compensado por la aliteración de la conjunción copulativa al comienzo de los versos sexto y octavo. El verso séptimo ('Feel the gladness of the May!') es trasladado mediante una transposición de grupo nominal a oración de relativo ('sentís el gozo que mayo trae') la cual arropa la idea heraclitiana de movimiento y del dinamismo en la naturaleza.

Los dos versos siguientes presentan sendas mutaciones tratando de plasmar un mensaje menos abstracto. El complemento circunstancial de lugar ('from my sight') sube un verso y se convierte en sujeto; el atributo (verso noveno) mantiene su función sintáctica a la vez que enfatiza la negatividad de la aseveración pues 'Be now fore ver taken from my sight' se convierte en 'Y aunque a mi vista esté ya negada'. El verso octavo incluye una inflexión al traducir 'the radiance' como 'la luz'.

El lamento o queja que Wordsworth articula en los versos siguientes es digna de mención ('Though nothing can bring back the hour/Of splendour in the grass, of Glory in the flower,') ya que 'hour' es especificada de forma más concreta ('esplendor') y los dos objetos directos, coordinados en el original, aparecen en disyuntiva en la traducción, ganando un encabalgamiento en la nueva versión ('(...) su esplendor/a la hierba (...)’). En este caso, el sustantivo 'glory' es trasladado como 'grandeza'. Añadamos que en las ocasiones anteriores ha sido vertido como 'esplendor'. La justificación de esta traducción como 'grandeza' no sólo es puramente lexicológica sino también prosódica, para evitar la repetición del otro adjetivo colindante 'splendour', potenciando así el efecto de la eufonía. 
En el acabado de esta serie queremos mencionar la traducción del último sintagma ('the philosophic mind') ya que es condensado a través del sustantivo, en plural, 'sabios'. Estamos de nuevo ante una modulación, en este caso de abstracta a concreta, que tiene en cuenta la etimología griega que engendra el adjetivo (proveniente del sustantivo ' $\varphi$ ı $\lambda \circ \sigma o \varphi a^{\prime}$ ') y que ajusta el sentido ante los lectores a los que Siles está aclimatando el texto.

11) La estrofa final sintetiza la filosofía del poeta. Su mente madura le permite amar la naturaleza así como la belleza derivada de aquélla. Los objetos naturales estimulan su pensamiento e incluso la flor más nimia que mece el viento puede conmoverlo y hacer que emanen en él hondos pensamientos: "thoughts that do often lie too deep for tears".

And O, ye Fountains, Meadows, Hills, and Groves,

Forebode not any severing of our loves!

Yet in my heart of hearts I feel your might;

I only have relinquished one delight

To live beneath your more habitual sway.

I love the Brooks which down their channels fret,

Even more than when I tripped lightly as they;

The innocent brightness of a new-born Day

Is lovely yet;

The Clouds that gather round the setting sun

Do take a sober colouring from an eye

That hath kept watch o'er man's mortality;

Another race hath been, and other palms are won.

Thanks to the human heart by which we live,

Thanks to its tenderness, its joys, and fears,

To me the meanest flower that blows can give

Thoughts that do often lie too deep for tears.

$Y$ vosotros prados, fuentes y arboledas,

¡no auguréis conclusión en nuestros amores!

Vuestro influjo aún lo siento en mi corazón

y sólo he renunciado a un deleite

para vivir en nuestro natural dominio.

A los arroyuelos que bajan retozando

los amos más que cuando yo saltaba como ellos.

El inocente resplandor del tierno amanecer

es bello todavía;

las nubes que rodean al sol poniente

menguan su fulgor ante los ojos

que han velado la muerte de un ser humano.

Es otra lid y se ganan otras palmas.

Gracias al corazón, que nos hace vivir, 
gracias a su ternura, sus gozos y sus miedos,

hasta la flor más humilde puede inspirarme

emociones tan hondas que no producen lágrimas.

El comienzo de esta última estrofa ' And O, ye Fountains, Meadows, Hills, and Groves' emula, como si de un ciclo natural o retorno se tratara, el comienzo del poema ('(...) meadow, grove, and stream': '(...) prado, arroyo y arboleda'). Ahora el traductor también prefiere cambiar el orden de los locativos e, igual que ocurre al inicio, se coteja un cómputo silábico creciente en la ordenación de los tres nombres. El verso tercero, por su parte, omite la redundancia que hay en el sintagma preposicional original ('in my heart of hearts': 'en mi corazón') expresando el mismo mensaje.

Siles mantiene muy literal la disposición de los elementos hasta el verso sexto, donde añade un diminutivo al objeto directo. Igualmente, el traductor aplica un encabalgamiento a la vez que antepone el objeto directo al verbo: 'I love the Brooks which down their channels fret, / Even more than when I tripped lightly as they;': 'A los arroyuelos que bajan retozando / los amo más que cuando yo saltaba como ellos?'El español antepone el elemento natural al que se refiere el afecto que radia del verbo. Además ha dado un giro poético a la parte final de la oración de relativo: 'which down their channels fret' es trasladado como 'que bajan retozando'. La prosopopeya original se prolonga en la traducción si bien le añade una cualidad de alegría al saltar, gracias al verbo 'retozar' como traducción del verbo 'fret'.

Los versos octavo y noveno ('The innocent brightness of a new-born Day / Is lovely yet,') mantienen su pálpito descriptivo, si bien especifican más la parte del día ya que traduce 'new-born Day' como 'tierno amanecer'. Otra vez se comprueba la adición de cualidades de afecto o cariño que el traductor aplica. Añadamos que al comienzo de la estrofa séptima, Siles traduce esta expresión ('Behold the Child among his new-born blisses,') de igual forma, lo que denota la coherencia en la selección de los términos a emplear.

Para finalizar, agreguemos dos observaciones sobre los tres versos últimos: 'Thanks to its tenderness, its joys, and fears, / to me the meanest flower that blows can give / Thought that do often lie too deep for tears'. De una parte destaca la simetría que mantiene el traductor; de otra su afán de ornamentar y poetizar su versión, ya que el predicado '(...) can give I Thoughts (...)' queda como '(...) puede inspirarme / emociones (...)'. El significado 'darme pensamientos' donarme pensamientos' es poetizado como 'inspirarme emociones' lo cual nos sirve para corroborar el anhelo y la disposición que José Siles Artés muestra y aplica para embellecer el poema. 


\section{NOTAS GENERALES SOBRE SU FORMA DE TRADUCIR}

Con las restas y adiciones desbrozadas, se aprecia en el texto meta un notable equilibrio entre la inteligibilidad del sentido y la redefinición del formato estrófico, completamente admisible en el polisistema de llegada, tanto en la esfera morfosintáctica, como en los planos semántico y estilístico.

Añadamos que Siles adapta el poema original a las normas de versificación del polisistema meta, manteniendo la diversidad silábica. Una vez cotejados los textos, podemos colegir que el traductor se acerca al polo meta tanto en los rasgos estilísticos como semánticos, recurriendo para su consecución a estrategias tales como las reseñadas transposiciones, modulaciones, equivalencias, compensaciones, concentraciones, particularizaciones, equivalencias e inversiones. En la mayoría de los casos se trata de estratagemas necesarias para no sobrepasar el molde estrófico al que vierte el contenido y para adaptarse a los diversos aspectos de la realización lingüística.

En suma, el criterio fundamental en el re-escritor es traducir tanto el fondo como la forma, introduciendo estas leves modificaciones en la anatomía morfológica del poema de manera que el resultado es otro poema distribuido con el mismo número de versos, potenciando dos constantes: el efecto poético, que embellece el texto, y el afán clarificador que acerca el contenido al lector.

Queda constancia en el análisis traductológico realizado que una de las mayores preocupaciones de Siles es mantener el contenido, también distribuido por estrofas, preservar el cómputo versal y conservar los matices de significado que centellean en el poema de Wordsworth por doquier.

De esta suerte, la norma inicial del traductor es plasmar el contenido icónico y metafórico del poema cuyo acabado lo consigue mediante una traducción oblicua y semántica, en verso, muy cercana a la traducción literal en ciertas frases y sometida al ajuste estrófico de la serie en inglés.

Estamos ante una obra representativa de la madurez del poeta lakista que refleja su idea sobre la vida en la tierra como sombra de un estado de existencia apriorístico y más puro, inmanente en la niñez y a posteriori borrado en el proceso de crecimiento. Es, en molde poético barnizado con herramientas lingüísticas complejas y sofisticadas, una recreación del capítulo séptimo de la República de Platón. El tema, que recuerda La infancia recuperada de Fernando Sabater (1976), desglosa la dicotomía neoplatónica de cuerpo y alma que ya expusiera Plotino en sus Enéadas. 


\section{OTROS TRABAJOS DEL ESCRITOR}

Si revisamos la bibliografía del autor, encontramos un rico legado literario y creativo. En un anaquel destacan sus escritos relacionados con la literatura inglesa cuales son "Shakespeare en España desde 1933 hasta 1964" publicado en Filología Moderna (15-16) (1964: 235-240); o su traducción de un libro de crítica literaria, El mundo vivo de Shakespeare (The Living World of Shakespeare de John Wain) (Alianza Editorial, 1964). Un trabajo de carácter filológico, particularmente de índole literaria comparatista, es el titulado "La influencia de don Quijote en Hudibras" que da a la estampa a través de la misma Revista (19-20, 1965: 185-192), en 1993 publica en Estudios de filología y su didáctica (II), a través de la Escuela Universitaria Pablo Montesino, su trabajo acerca de "Una tripe traducción de Ozymandias" (263-269); en los IV Encuentros complutenses en torno a la traducción que organiza el Instituto Universitario de Lenguas Modernas y Traductores, imparte la conferencia titulada "Los sonetos de Shakespeare: Modos de traducción de poesía inglesa" que luego ve la luz gracias a la Editorial Complutense, en forma de artículo en 1994 (427-432).

Llevando la mirada hacia otro anaquel de su labor literaria, hemos de reseñar obras de creación, que las dividimos en poemarios, poemas en prosa y narrativa. Su primer libro de versos, Papeles palabras (1972), es de carácter intimista. El segundo, Poemas de Madrid (1986), es una ejemplo de poesía urbana, mientras que en los dos volúmenes siguientes, Coplas de Río de Aguas (1991) y Cantares de Almería (1993), el poeta se recrea en el cultivo de la canción y la copla popular.

Respecto a la prosa, compuesta con acentos líricos, citemos las tres obras siguientes, Diario de un veraneante insomne (2003), Diario de un poeta de café (2005) y La palmera del Malecón (2008), que dan expresión a sensaciones, cavilaciones y visiones al hilo de los días. En su legado narrativo, desde los brumosos relatos primerizos de Umbrales (1963), el escritor publica dos novelas de corte realista, La urna lacrada, historia de unas oposiciones (1980) y Los tranvías de Granada (1998 y 1999); más otras tres, Spain is different (1994), Paseo del Príncipe (1999) y Garrucha, estampas sobre la guerra civil y la posguerra (2001), en las que aflora una vena humorista-faceta que ya inspirara el glosario, Typical Catalan. Guía para castellanoparlantes (1981)-

Otro trabajos encomiables son su tesis doctoral, de la que podemos disfrutar una edición reducida publicada como El arte de la novela pastoril (1972) u otros libros didácticos ya que José Siles Artés es coautor en una Fonética correctiva del inglés (1979) y en La pronunciación del Inglés para hispanohablantes(1998), además es coautor o autor de más de veinte libros para la enseñanza del español a extranjeros, entre los que cabe aquí destacar sus Historias para conversar (1999), una serie de cuatro tomitos, 
en los que la escritura literaria sirve de base para el aprendizaje de la lengua.

\section{VALORACIÓN DE CONJUNTO}

Estamos ante un poeta que se asoma a las nuevas tecnologías y tiene incluso su blog y sus propios apuntes de "Poemas comentados" donde el lector interesado puede aprehender mejor su ideario estético así como las motivaciones que le hacen escribir algunos versos. Desde el punto de vista de la pragmática, otro dato que deseamos resaltar en estas ideas de conjunto es su diálogo con los lectores ya que José Siles no desdeña exponer la traducción de un verso determinado para recabar información de los lectores de su blog virtual. En los poemas comentados leemos "Con Machado" cuyos siete versos dicen lo siguiente:

Caminante, no hay camino,

se hace camino al andar.

Camina caminante, camina,

camina sin parar,

que caminando, caminante,

tus sueños llevarás.

Se trata de una cancioncilla que ora junta un racimo de oclusivas ora canta un ramillete de nasales. Cultiva germinaciones léxicas y hace rima asonante en los pares. La musicalidad del texto desea que siga ofreciendo nuevos trabajos.

Con todo, antes de concluir este artículo, si miramos de modo retrospectivo a la trayectoria de José Siles Artés como traductor de poesía, se aprecia un interés por la traducción literaria en sus primeros años de escritor, vocación que le ha acompañado siempre y que vuelve a fructificar una y otra vez. Bien podemos aplicarle, realizados los sueños, su proclama machadiana no para exhortarle a transitar el camino sino para felicitarle.

\section{CONCLUSIONES}

Si valoramos, en su conjunto, la trayectoria del traductor que nos ocupa, se vislumbra una clara evolución personal y profesional, aunque la vocación poética le acompañe durante toda su singladura, pues el que fue guía turístico se dedica a elaborar herramientas pedagógicas y se entrega a la creación literaria sea ésta a modo de poeta o en forma de poetatraductor.

Otro valor que queremos destacar es su carácter pionero ya que en la década de los sesenta no hemos hallado muchos traductores de poesía inglesa y nos ha sido difícil encontrar alguna obra de conjunto como la que Siles Artés da a la luz de la imprenta. 
De los poetas de Cumbria traduce los siguientes magnos poemas: "Ode. Intimations of Immortality from Recollections of Early Childhood" ("Oda. Signos de inmortalidad en los recuerdos de la temprana infancia"), de Wordsworth; una selección "From the Rime of the Ancient Mariner" ("De la balada del marinero de antaño") y el famoso "Kubla Khan" de Coleridge. "The Widow" ("La viuda") de Robert Southey.

Derivado del análisis realizado y a modo de conclusión podemos afirmar que Siles conserva el macrocosmos lingüístico y retórico del texto fuente con bastante acierto y maestría. El traductor adopta como norma inicial un criterio semántico y poético que amolda el texto origen tanto en estrofas como en su significado. Las transformaciones señaladas en el análisis evocan a los ojos del receptor un lenguaje muy poético, nítido y claro. José Siles Artés mantiene el verso como unidad de traducción, tratando de pergeñar acertadamente una equivalencia armónica y equilibrada tanto en la forma o estructura superficial como en el fondo o estructura profunda del poema.

En efecto, la persona que se acerque a la poesía de José Siles Artés va a encontrar, además de un deseo imperioso de difusión cultural y literaria, una belleza contenida en los versos mismos a los que podemos aplicar con justicia su misma traducción del poema de Keats "Ode on a Grecian Urn" (1920): 'Beauty is truth, truth is beauty, -that is all / Ye know on earth, and all ye need to know': 'La belleza es verdad y la verdad es belleza. / No hay necesitáis más saber'.

REFERENCIAS BIBLIOGRÁFICAS

ABRAMS, M.H. A Glossary of Literary Terms. New York: Harcourt Brace \& Company, 1993

AlCARAZ VARó, E. Review. Antología bilingüe de la poesía angloamericana (Siglos XIV-XIX, en Revista alicantina de Estudios Ingleses, vol. 20, noviembre de 2007, 435-446.

ARISTOTLE. "Poetics." Trad. S. H. Butcher. Critical Theory Since Plato. Ed. Hazard Adams. New York: Harcourt Brace Jovanovich College Publishers, 1992. 50-66.

ColeridGE, Samuel Taylor. "Christabel." The Norton Anthology of English Literature. Ed. M. H. Abrams. Vol. 2. New York: W. W. Norton \& Company. 349-364.

" "From Biographia Literaria." The Norton Anthology of English Literature. Ed. M. H. Abrams. Vol. 2. New York: W. W. Norton \& Company. 378-395.

,"Kubla Kahn: Or, A Vision in a Dream. A Fragment." The Norton Anthology of English Literature. Ed. M. H. Abrams. Vol. 2. New York: W. W. Norton \& Company. 346-349. 
, "The Rime of the Ancient Mariner." The Norton Anthology of English Literature. Ed. M. H. Abrams. Vol. 2. New York: W. W. Norton \& Company. 330-346.

Dietz Guerrero, B. "Introducción" a M. A. García Peinado \& J. P. Monferrer, Poetas románticos universales. Antología bilingüe. Córdoba: Servicio de Publicaciones de la Universidad de Córdoba. 1998: 9-14.

LONGINUS. "On the Sublime." Trad. W. R. Roberts. Critical Theory Since Plato. Ed. Hazard Adams. New York: Harcourt Brace Jovanovich College Publishers, 1992. 76-98.

WORDSWORTH, W. \& S. T. COlERIDGE, "From Preface to Lyrical Ballads." The Norton Anthology of English Literature. Ed. M. H. Abrams. Vol. 2. New York: W. W. Norton \& Company. 141-152.

SILES ARTÉS, J.. Poesía inglesa.. Antología bilingüe. Barcelina: Notas Literatura, 1979.

Poesía angloamericana. Antología bilingüe. Valencia: L`Eliana, 2006.

TorRalbo CABallero, J. D. Breve panorama de la traductología. Materiales de traductología: teoría y práctica. Granada: Grupo Editorial Universitario, 2008. 


\section{Apéndice de José Siles Artés: Traducir poesía, transmitir poesía}

\section{EL OFICIO DE LA TRADUCCIÓN}

Pocos menesteres habrá más necesarios y al mismo tiempo más sospechosos. Lo de necesario es tan evidente que sería superfluo resaltarlo aquí. Lo de sospechoso es un estigma del género traducción, en cuanto su resultado, su fruto, es siempre carne viva expuesta al ojo crítico. Fallos, malentendidos, incorrecciones, infidelidades, quedan en el texto sembradas para el lector de destino, quien si además posee algún conocimiento de la lengua de origen, tenderá fácilmente a proponer alternativas. Opinar sobre la calidad de un texto traducido es tan corriente como opinar sobre la enseñanza. Rara es la persona que no se considera un maestro competente.

No hay desde luego traducción perfecta, como no hay texto original perfecto, aunque sí es evidente que hay traducciones más o menos buenas, bondad que engloba los atributos de fidelidad, soltura y naturalidad expresiva en la lengua de destino.

En gran medida, la traducción de calidad es la que menos llama la atención. Es la que menos se hace notar, pasando por discurso original, y por eso quizá suscita menos comentarios, quizá algún elogio más o menos sucinto. En cambio la de menos quilates tiene asegurado el rechazo y la queja, los puntos sobre las íes.

El conocido dicho, "traductor, traidor", encierra la señalada transparencia del oficio, en el que fácilmente saltan a la vista los significados mal vertidos y los matices omitidos o desvirtuados. Destaca mucho más lo que el traductor no traslada, o traslada mal, que lo que sí traslada.

Vamos a examinar a continuación algunos ejemplos representativos. En 1918 aparece el libro, Las cien mejores poesías (líricas) de la lengua inglesa, "traducidas directamente en verso por Fernando Maristany. Prólogo de Enrique Díez Canedo"1, del cual tomo el soneto LXXIII, de William Shakespeare, que dice así:

En mí ves la estación en que colgar

Se ven solo unas hojas amarillas

De las ramas-que el frío hace temblar-

Do cantaron gentiles avecillas.

\footnotetext{
${ }^{1}$ Editorial Cervantes, Valencia, p. 9.
} 
En mí ves el ocaso que convierte

El día, al degradar, en noche obscura,

Cual otro Yo distinto de la Muerte

Que envuelve toda cosa en su negrura.

En mí ves el ardor de un fuego tal,

Cual vio la juventud que ya es ceniza;

Como el lecho de muerte sobre el cual

Quien prestárale vida ahora agoniza.

Bien lo ves, pues temiendo que me muera,

Me vas amando ya de otra manera.

Salta al oído y a la vista inmediatamente que el traductor ha adoptado un esquema clásico de soneto, con tres cuartetos y un pareado, rimando los primeros en alternancia, primero con tercero y segundo con cuarto. La rima es consonante y, normativamente, los versos son endecasílabos. Estamos ante un artesano competente, diestro, y al mismo tiempo un conocedor de los recursos léxicos y sintácticos de la lengua en que escribe. Esas cualidades las revela ya el primer cuartero, donde encontramos: un hábil manejo del hipérbaton que se extiende por los tres primeros versos; un atinado empleo del arcaísmo "do", y una no menos afortunada presencia del vocablo "avecillas", sinónimo de pajarillos, un evidente casticismo poético. En el segundo cuarteto a mí, personalmente, me disuena la pareja "al degradar", pero acepto todo el resto del poema como una composición fluida, biensonante y con sentido desde el principio hasta el fin.

Encarando ahora el texto de Shakespeare, nuestro oído percibe una alternancia de sílabas fuertes y débiles que carece de equivalencia en castellano, donde la altura de unas y otras está bastante más nivelada. Los saltos prosódicos del inglés, además, están regularmente utilizados por el poeta para proyectar una fisonomía rítmica. Se trata en definitiva del recurso de pies acentuales, cinco en el verso del soneto, que es característico de la lengua inglesa. La disparidad es grande, pues, en el plano prosódico, si bien en el rítmico, Maristany no ha tenido problema para calcar la plantilla de primero con tercero y segundo con cuarto de los cuartetos originales ${ }^{2}$.

That time of year thou mayst in me behold

When yellow leaves, or none, or few, do hang

Upon those boughs which shake against the cold,

Bare ruin'd choirs, where late the sweet birds sang.

${ }^{2}$ En p. 1320 de William Shakespeare. The Complete Works, Collins, London and Glasgow, 1951 
In me thou see'st the twilight of such day

As after sunset fadeth in the west;

Which by and by black night doth take away,

Death's second self, that seals up all in rest.

In me thou see'st the glowing of such fire,

That on the ashes of his youth doth lie,

As the death-bed whereon it must expire,

Consum'd with that which it was nourish'd by.

This thou perceiv'st, which makes thy love more strong,

To love that well which thou must leave ere long.

No nos explica Fernando Maristany sus criterios de traductor, pero aparte de que su obra lo pone muy claramente de manifiesto, la respuesta se precisa inequívocamente en el prólogo del notable crítico y poeta Enrique Díez-Canedo. Según éste:

El verso en la poesía es esencial; una traducción en verso puede ser equivalente a su dechado, aunque no sea esto lo que suele ocurrir; una traducción en prosa, por buena que sea, queda siempre en un grado inferior. Le faltan la "góndola de nácar" y "las alas de cisne" de que habló Zorrilla. La traducción en prosa cumple, a decir verdad, fines distintos: es ayuda de la curiosidad o del trabajo científico, nace muerta. La traducción versificada, si es buena, infunde nueva vida al modelo ${ }^{3}$.

Está claro que cuando Díez-Canedo habla de la "traducción en verso", se refiere a la que sigue las pautas de medida y rima, y todo lo que no cumpla esos requisitos, es "traducción en prosa". Es una distinción de blanco o negro que, como vamos a ver en seguida va a quedar pronto-está quedando yaanticuada entre los poetas españoles.

No era poeta, sino gran erudito, Luis Astrana Marín, traductor de las Obras Completas de William Shakespeare, aparecidas en 1930, y que van a gozar de un prestigio y una vigencia que llegan hasta nuestros días. Aquí los sonetos de Shakespeare están vertidos en prosa, la forma que tanto Maristany como Díez-Canedo consideraban de "segundo grado".

El mismo soneto, el LXIII, lo traslada Astrana Marín así:

Puedes contemplar en mí esa estación del año

en que las hojas amarillas, unas cuantas o tal vez ninguna,

penden de las ramas que tiemblan bajo los vientos fríos,

\footnotetext{
${ }^{3}$ Op. cit., p. VI.
} 
coros desnudos y desolados, donde poco ha cantaban gentiles ruiseñores.

Ves en mí el crepúsculo del día, cuando se funde en el ocaso tras la puesta del sol, y que extingue poco a poco la sombría noche, segunda persona de la muerte, que sella todo con el reposo.

Ves en mí el resplandor de un fuego que yace sobre las cenizas de su juventud, como sobre el lecho mortuorio en que debe expirar, consumido por la llama que le nutría.

He aquí lo que percibes, que robustece más tu amor para amar tiernamente lo que habrías de abandonar dentro de poco ${ }^{4}$.

El soneto de Shakespeare ha sido recompuesto en cuatro párrafos, cada uno correspondiente a una estrofa del original. Son eso, párrafos, en que los versos están transcritos a renglón seguido, con las rimas previamente amputadas. Esto es de recalcar, ya que la sílaba final de un verso clásico es rimante con la final de otro verso en posición más o menos cercana. De esta manera cada línea del poema concluye con una voz que levanta la expectativa de un eco, lo que naturalmente demanda una pausa o un realce. Al prescindir de esta entrecruzada musicalidad, del juego repetitivo de sílabas homófonas a intervalos regulares, la composición de Astrana se enmarca en el género de la prosa. Quizá de la llamada "prosa poética", ya que la simplificación no afecta al alma lírica del soneto, que puede oírse latir en la escritura resultante.

Simultáneamente se observa que el remedo en prosa contiene más palabras que el soneto. Ciento treinta he contado yo, por ciento veintiuno del original. Es una holgura que permite "recuperar" la metáfora, "bare ruin'd choirs", que Astrana llama "coros desnudos y desolados". Maristany la sacrificó, agobiado por la rígida brevedad de sus versos.

Queda muy claro el método de Astrana Marín en la "Introducción" a las Obras Completas de Shakespeare ${ }^{5}$ :

Hay varias opiniones sobre si se debe traducir a un poeta en verso. Puede asegurarse que ninguna traducción en verso es buena, aun la de Jáuregui del Aminta, del Tasso, que tanto ponderaba Cervantes. La razón obedece a que unas veces la métrica y otras la rima impiden permanecer fieles al autor.

${ }^{4}$ En p. 2175 de William Shakespeare. Obras Completas, Aguilar, Madrid, 1951.

${ }^{5}$ Ibidem, p. 19. 
La obligación del traductor, pues, es decir todo lo que el autor dice-la calidad es sinónimo de fidelidad. Ahora bien, aun prescindiendo de la métrica, aun tratando de ser literal, Astrana Marín asegura no ser esclavo de Shakespeare, definiéndose como seguidor de "un método ecléctico". Así se explicaría que en el soneto que estamos considerando haya traducido "sweet birds" por "gentiles ruiseñores", una flagrante infidelidad, aunque poéticamente aceptable. Y merece comentario aparte el pareado final, la conclusión del soneto, donde precisamente Maristany sabe revelarnos la hondura y la paradójica resurrección del amor expresados por el poeta:

Bien lo ves, pues temiendo que me muera,

Me vas amando ya de otra manera.

Hay ahí un tú y un yo íntimamente ligados, co-entrañados por un amor que con la proximidad de la muerte cobra trágico relieve. Literalmente, "fielmente", Astrana Marín cumple, prueba su competencia:

He aquí lo que percibes, que robustece más tu amor

para amar tiernamente lo que habrías de abandonar dentro de poco.

Pero con dos palabras, dos palabras tan sólo, hace naufragar la conclusión. Suscribe un "lo que" neutro, ajeno a una subjetividad, a un yo doliente en quien descansa el sentido último del poema.

Un acontecimiento trascendental para la poesía española fue el contacto y el interés de Juan Ramón Jiménez, el "Andaluz Universal", con la poesía inglesa y norteamericana y, gran lector y traductor de Yeats, no podía pasarle desapercibido este breve poema ${ }^{6}$, que tiene conquistado un sitio en las antologías al uso:
AN IRISH AIRMAN FORESEES HIS DEATH
I know that I shall meet my fate
Somewhere among the clouds above;
Those that I fight I do not hate,
Those that I guard I do not love;
My country is Kiltartan Cross,
My countrymen Kiltartan's poor,
No likely end could bring them loss
Or leave them happier than before.
Nor law, nor duty bade me fight,
Nor public men, nor cheering crowds,

${ }^{6}$ En p. 69 de W. B. Yeats. Selected Poetry, edited with an Introduction and Notes by A. Norman Jeffares, Macmillan, London, 1972. 


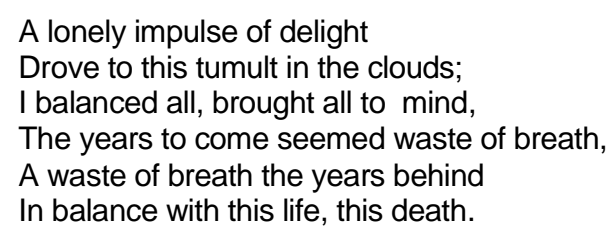

Su hechura es rotunda y evidente: dieciséis versos, cuatro cuartetos con rima alternada y cuatro acentos por verso. Los artificios empleados son la repetición (versos 3-4, 5-6, 9-10, 14-15). Respecto al fondo, sobresale una fatídica declaración en los versos 1-2; una enunciación paradójica en el 3-4, la expresión de un desengaño en 5-8, y una explicación de motivos que va desde el verso 9 al 16. Verso este último, el 16, que anuncia el presentimiento o la vivencia de la muerte del aviador con una simplicidad expresiva que resulta estremecedora. La versión de Juan Ramón Jiménez es la siguiente:

\begin{abstract}
UN AVIADOR IRLANDÉS PREVÉ SU MUERTE
Yo sé que he de tropezar con mi destino en algún alto lugar de las nubes. No odio a quienes combato ni amo a los que defiendo. Mi tierra es la Cruz de Kiltartan, mis paisanos, los pobres de Kiltartan. Ningún fin posible podría perjudicarlos ni hacerlos más felices. Ni ley ni deber me exijen que pelee, ni políticos ni multitudes vitoreantes; un solitario impulso de delicia me echa a este tumulto de las nubes. Todo lo sopesé, todo lo vi de golpe: los años venideros serían un desperdicio de afán, un malbarato de afán los años caídos, puestos contra esta vida, esta muerte.
\end{abstract}

Sorprende a primera vista que la traducción sea en prosa, proviniendo de un poeta puro por excelencia, con una capacidad excepcional, quizá inigualada, para dar alas y música a cada verso que compone. Una segunda mirada, un examen de la evolución poética de Juan Ramón Jiménez, nos da probablemente la clave de por qué vertió aquel poema en prosa. Como hemos adelantado arriba, en las primeras décadas del siglo XX, la poesía española va a ir incorporando cambios formales que antes eran tenidos por antiestéticos y patentemente pedestres y sacrílegos. La "góndola de nácar" y las "alas de cisne" aludidas por Díez-Canedo se van depreciando para ir dejando campo a un verso más directo y libre, bien entendido que las dos escuelas coexistirán, incluso dentro de la producción de un mismo poeta.

A la nueva y pujante ola se aupó de manera deliberada y apasionada Juan Ramón Jiménez. Casi todo su Diario de un poeta recién casado, que vio la luz en 1917, está escrito en verso libre, que el autor llamó "verso 
desnudo", del que se considera el introductor en la poesía española ${ }^{7}$. Este verso está tan cerca de la prosa que podría escribirse como tal, llegando a afirmar: "Al escribir en prosa un poema, al escribirlo seguido, la poesía gana",

Yo, lo confieso, no sé dónde está el vuelo, ni el brillo, ni la música en la pieza transcrita. Personalmente no percibo que transmita mucha emoción lírica., y aunque no se aparta del sentido del original, introduce sintagmas de índole extravagante, como "un solitario impulso de delicia", un "desperdicio de afán", "un malbarato de afán" y "los años caídos", todos los cuales llamarían menos la atención en un traductor amateur. Tal y como nos la ha dejado nuestro poeta, esta versión parece más bien un borrador, una primera tentativa en espera de una transfusión de su genio poético. $O$, también es posible, quizá nunca fue esa su intención; quizá ésta no es más que la flor libada, succionada por la ávida sensibilidad del genio.

Otro gran poeta moderno español, Luis Cernuda, fue traductor de poesía. De los ingleses tradujo a Marvell, Blake, Keats, Browning y Yeats. De Keats seleccionó su Ode to Autum, la última y más elaborada de sus seis odas, conjunto artístico de primer orden, una de las cumbres de la poesía inglesa.

Este poema consta de tres estrofas, cada una con once versos de cinco acentos. Una lectura reposada, y mejor una doble lectura, nos obsequia inevitablemente con una abundancia melódica, sustentada por la regular sucesión de pies rítmicos, con alternancia de sílabas fuertes y débiles, que la primera estrofa despliega de esta manera ${ }^{9}$ :
Season of mists and mellow fruitfulness,
Close bosom-friend of the maturing sun;
Conspiring with hím how to load and bless
With fruit the vines that round the thatch-eves run;
To bend with apples the moss'd cottage-trees,
And fill all fruit with ripeness to the core;
To swell the gourd, and plump the hazel shells
With a sweet kernel; to set budding more,
And still more, later flowers for the bees,
Until they think warm days will never cease,
For Summer has o'er-brimm'd their clammy cells.

\footnotetext{
${ }^{7}$ V. pp. 24-27 de la Introducción de Michael P. Predmore a su edición del Diario de un poeta recién casado (1916), Cátedra, Madrid, 2001.

${ }^{8}$ En p. 115 de Conversaciones con Juan Ramón Jiménez, de Ricardo Gullón, Taurus

Edidiones, Madrid, 1958.

${ }^{9}$ En pp. 107-108 de Keats. Selected Poems and Letters, chosen and edited by Roger Sharrock, Oxford University Press, London and Southampton, 1964.
} 
Encarando el cuarteto de apertura, vemos que cada verso ofrece el mismo perfil cadencial, pero los cuatro en conjunto componen una canción con dos repeticiones silábicas o rimas, en este caso consonantes, primera con tercera, segunda con cuarta, AC, BD. Son notas claras y rotundas, ecos repetidos que emparejan sílabas familiares, entrañables.

No son los únicos recursos poéticos; nótese la eme aliterativa del primer verso-mist-mellow-, consonancia ancestral de la poesía anglosajona. O la más sutil del cuarto verso-round...run.

Simultáneamente, cada verso es una aseveración de hondo sentido lírico, y la estrofa una sucesión de percepciones metafóricas que no se detienen en el verso cuarto. Digo que no se detienen porque estas cuatro líneas son la tercera parte de una estrofa que discurre con igual magia hasta el verso once, y así las dos estrofas restantes. Por las limitaciones de espacio y tiempo no cabe extender más el análisis estético, urgiendo ya considerar qué tipo de traducción o versión al castellano llevó a cabo Luis Cernuda ${ }^{10}$.

\section{ODA AL OTOÑO}

Época de neblinas, de fértiles sazones,

Compañera entrañable del sol casi maduro,

Conspirando con él cómo llenar las viñas

Que escalan por las bardas con bendición de frutos

O encorvar con manzanas los árboles del huerto.

Eres tú quien los frutos sazonas hondamente,

Hinchas la calabaza, la cáscara morena

Llenas con dulce almendra, y tan diversos brotes

De flores ya tardías regalas a la abeja,

Que los cálidos días supone interminables,

Desbordando el verano de sus celdas viscosas.

Sintácticamente se sigue la senda marcada hasta el verso sexto, donde el poeta se dirige al otoño en segunda persona, un recurso muy apreciado por Cernuda, y que ciertamente es utilizado por Keats en esta oda, aunque no surge hasta la segunda estrofa.

En general el traductor se mantiene fiel al sentido del original, si bien se observan algunas tosquedades que rebajan la calidad de su trabajo. Son como metal sin refinar, ganga buena que oculta el lustre precioso. Son expresiones como "el sol casi maduro", "los frutos sazonas hondamente", "la cáscara morena" o "... los cálidos días supone interminables". Su presencia, si no chirriar, puede por lo menos extrañar al lector.

\footnotetext{
${ }^{10}$ En pp. 749-750 de Poesía, vol. I de Obra completa, edición a cargo de Derek Harris y Luis Maristany, Siruela, Madrid, 1994.
} 
En el plano formal notamos que la traducción consta de once versos, igual número que el original. En éste hay rimas, en aquélla, no, si bien Cernuda consideró apropiado atenerse a una cierta regularidad, a una medida reiterada. Sus versos, si contamos las sílabas, se componen de catorce, número que los engloba en la muy consolidada categoría de "alejandrinos". Es una adopción inteligente, que le proporciona holgura para encasillar el más denso y sintético verso inglés, que al travestirse en castellano tiende a alargarse, a ocupar más espacio. Al mismo tiempo el adaptador consigue dar un son reconocible a sus líneas. Los alejandrinos contienen dos hemistiquios de siete sílabas, en medio de los cuales se forma de manera natural una pausa, garantía cadencial de esta medida, que algo tendrá que ver con su intermitente vigencia a la largo de los siglos. Haciendo sonar las cuerdas de tan antigua lira, Cernuda revela una creencia firme en la contextura y arquitectura del poema, construido a base de versos homométricos, pero individualizados, unidades melódicas diferenciadas que se transcriben separadas unas de otras. Nada que ver con la pretendida identidad entre prosa y verso contemplada por Juan Ramón Jiménez.

TRADUCIR POESÍA, TRANSMITIR POESÍA.

En el océano de la prosa, con el compás y el timón de las gramáticas y los diccionarios, el traductor puede navegar y llevar a cabo travesías más o menos afortunadas. En el mar de la poesía, sin embargo, esos instrumentos, siendo desde luego indispensables, le ofrecen una azarosa garantía de éxito. $Y$ aquí hemos embestido un escollo tan real como indefinible: qué cosa es prosa, qué cosa es poesía.

Hay tantas definiciones de poesía seguramente como pensadores que se hayan ocupado del concepto, diversidad que apunta a concluir que este género literario es todas esas cosas que se dicen de él, y que ninguna lo abarca totalmente. Definir es encerrar, pero que yo sepa, la poesía ha logrado hasta hoy librarse de toda prisión definitoria.

Los niños y los simples dicen a veces las grandes verdades, y creo que este es el caso del gentilhombre de Molière cuando descubrió que "todo lo que no es prosa es poesía, y todo lo que no es poesía es prosa". La carcajada del auditorio teatral está asegurada cada vez que el actor correspondiente pronuncia esta declaración, pero ahondando un poco en ella, ahora que nos estamos ocupando de estos dos géneros literarios, nos percatamos de que aquel nuevo rico que quería adornarse con las plumas de las artes y las buenas maneras, estaba en el fondo enunciando una sagaz aproximación a los géneros prosa y poesía. Veía lo que eran por contraposición uno del otro. Veía que eran diferentes, aunque no sabía decir en qué consistía la diferencia. 
Lo que parece evidente, sin embargo, es que la poesía es prosa con algo más. O dicho de otra manera, si a un poema se lo desengalana, si se lo despoja de los efectos que le confieren entidad de poesía, queda convertido en un cuerpo desnudo, en una criatura en cueros, en un texto de prosa.

El traductor que se limita a trasladar la prosa de un poema, ese cuerpo desnudo al que nos hemos referido, lo tiene mucho más llevadero que el que, con más ambición, se proponga trasladar o transmitir poesía. Su faena se restringe al constituyente semántico básico del poema. Este traductor, al que podríamos llamar "pragmático", se aplica a trasladar lo que dice el poeta, dejando a un lado el cómo lo dice. Resumiendo, y para recurrir a la terminología de la lingüística, podríamos hablar de que el traductor pragmático se ha quedado en el "significado", dejando de lado el "significante".

Pero ¿cuál es propiamente el significante de un poema? ¿En qué consiste lo que se ha dejado en el tintero el traductor pragmático que nos ha ocupado hasta ahora? Básicamente la respuesta se halla en que se ha operado una transformación a una lengua diferente, a un código fonético distinto. Un poema, un poema clásico, tradicional, está articulado en una serie de versos medidos y acentuados de una manera determinada que no tienen equivalencia en la lengua de destino. Ahora bien, las disparidades pueden ser de mayor o menor grado. Tratándose de traducir de una lengua románica a otra del mismo tronco, es evidente que existen ciertas similitudes y paralelismos. Se pueden hacer, y se han hecho y se hacen calcos de recursos fónicos entre ellas, lo que entre una lengua germánica y una románica es imposible. Una tarea es traducir poesía italiana o francesa al castellano, y otra bien diferente, y mucho más ardua, traducir del alemán o del inglés.

El traductor pragmático, reparemos, no puede casi nunca evitar ser víctima de una sutil ironía. Su obra, por muy tosca que la haya forjado, sigue oliendo a poesía. Me explico. El poema, sobre todo el de calidad, es la expresión de una mente lúcida y sensible. Es un mensaje más o menos original, una visión más o menos subjetiva que reclama la atención de un oyente $o$ un lector. Lo que el poeta dice justifica la traducción, y cuando aquello tiene un valor lírico, emotivo, sentimental, es difícil que no se manifieste en esa versión acuñada en prosa, de la cual se sacará más jugo cuanto más iniciado se esté en la lectura de poesía. Este género literario lleva impregnadas unas calidades, unos efectos, unas connotaciones, que el traductor difícilmente puede obviar. Se puede trasladar un poema en prosa, se ha hecho y se sigue haciendo, pero aún así el aroma poético del original difícilmente se evaporará totalmente. 
Personalmente, como traductor, me preocupa que se disipe lo menos posible de aquella esencia. Aspiro siempre a componer en castellano una pieza lírica moldeada sobre el original; o dicho de otra manera, lo que me motiva principalmente es transvasar poesía, afán seguramente presente en la mayoría de los traductores, pero cuya intensidad varía en función del grado de importancia que se dé al significado del verso frente a su virtud lírica. En resumen, la virtud poética del original presenta un número de problemas que piden respuesta, pero como algunos de ellos carecen de solución en la lengua receptora, estimo que se debe optar por una selección viable, por uno o varios artificios que mínimamente den un cariz poético a la versión resultante. Esto es para mí "transmitir poesía".

Paralelamente valoro la claridad del texto producido, de tal modo que las palabras aisladas y las frases no han de ser más oscuras o ambiguas que las del original; la sintaxis subordinada y la concatenación de los versos debe ser aceptada sin extrañeza por el oído del hispano-parlante; la lengua utilizada debe proceder del patrimonio corriente, del acerbo lingüístico habitual en la conversación o en la lectura, evitándose las expresiones extravagantes o torpes. Un poema traducido debe sonar con la naturalidad de un texto escrito originariamente en español.

En lo concerniente a la fidelidad, no siempre aporto la equivalencia literal de una palabra o una frase, sino una traducción aproximada, y a veces hasta inexacta ¿Por qué? Porque un significante concreto de inequívoca índole poética, puede perder su aureola al convertirse, al transmigrar a otra lengua, dándose el caso menos grave cuando la palabra española es simplemente mate, y el peor cuando tiene connotaciones coloquiales específicas que le dan perfil de cuerpo raro, exótico, en el seno del poema.

En el proceso de traducción de un poema puede presentarse la conveniencia de una recreación más o menos parcial; de decir algo que no dice la lengua original, pero que la lengua de destino sí puede expresar con mayor brillantez, encanto o profundidad. No es una circunstancia corriente, pero tampoco rara. El traductor se ve entonces en el aprieto de ser literariamente infiel, de recurrir a exclusivos matices de su lengua, debatiéndose entre la conciencia sin mancha y el morbo de la transgresión.

En repetidas ocasiones, debo confesar, he caído en dicha tentación; como en mi traducción de An Irish Airman Foresees his Death ${ }^{11}$, que transcribo a continuación. En los cuatro últimos versos, sobre todo, puede verse una recreación, que me ha parecido más acorde con la lengua española que una traducción literal.

${ }^{11}$ En pp. 158-159 de Poesía angloamericana. Antología Bilingüe (Siglos XIV al XX). Selección, traducción, introducción, semblanzas y notas de José Siles Artés, La Torre del Virrey, Revista de Estudios Culturales, Ajuntament de L'Eliana (Valencia), 2006. 


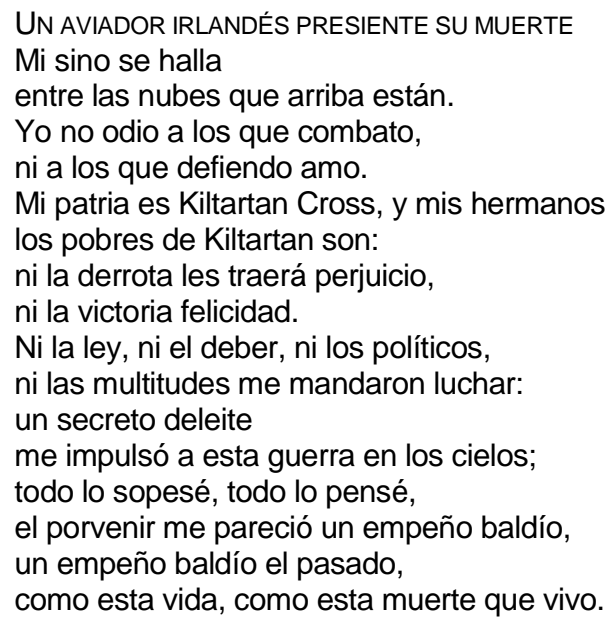

$\mathrm{Y}$, finalmente, cabe hacerse la siguiente pregunta: ¿Existe algún método, algún procedimiento para seleccionar los vocablos más apropiados, los que convenzan y al mismo tiempo cautiven? Yo no lo conozco; en cada caso tengo que sumergirme en la niebla del instinto y tantear con tenacidad hasta dar con una luz salvadora. Pero, ¿no es esa también la eterna búsqueda del creador del poema? 